\title{
HORMONAL CHANGES DURING FORMATION AND INVOLUTION OF CORPUS LUTEUM IN RABBITS
}

\author{
F. LABIB, E. A. EL AZAB, and F. A. SOLIMAN
}

Department of Physiology, Faculty of Veterinary Science, University of Khartoum, Sudan

Received October 25, 1976

\begin{abstract}
Labib F., E. A. El Azab, F. A. Soliman: Hormonal Changes During Formation and Involution of Corpus Luteum in Rabbits. Acta vet. Brno, 47, 1978: 23-31.

A study was made on 30 female Boscat rabbits to reveal the hormonal changes, namely, TSH, FSH, LH and LTH during the formation, maintenance and involution of the corpora lutea. Induction of ovulation was done by using gonadotrophic hormones (PMS and HCG). After HCG injection the animals were devided into 3 groups of 10 animals each. They were slaughtered after 3, 7 and 15 days from HCG injection. The results observed from this experiment are as follows:
\end{abstract}

3-day old corpus luteum

The rate of synthesis and release of TSH and state of thyroid were considered in a stabilized, balanced euthyroid status. There was increased concentration of FSH in the pituitaries with a relatively low level in the blood. This indicates the inhibition of release of FSH at this stage of development of corpora lutea.

The level of LTH in the pituitary was of an average value and low in the serum.

7-days old corpus luteum

The TSH content of the pituitaries was the lowest (decreased synthesis) with a mild change in its level in the blood (non-significant). The thyroids were relatively less active than in the previous group.

The FSH content of the pituitaries and blood were significantly decreased (decreased synthesis and release of FSH). The LH content of the pituitaries was increased and the level in the blood was decreased (decreased release of LH).

The LTH content of the pituitaries was relatively low, while that of the blood was maximal, indicating increased release of LTH.

15-day old corpus luteum

The TSH content of the pituitaries and blood were highest indicating increased synthesis and release of this hormone. The thyroid gland showed maximum activity as compared to the previous groups.

The FSH content of the pituitaries was relatively low while it reached its maximum in the serum (increased rate of release of FSH). The level of LH in the pituitaries was low and that of the blood was the least. The LTH content of the pituitaries was at its maximum and it was the lowest in the blood (increased synthesis of LTH but blocked release into the blood). The results are discussed in the text.

LTH, TSH, LH, FSH, pituitary, blood serum.

The features of growth and maintenance of the corpus luteum, and its subsequent involution are active processes of extreme importance in regulating reproductive performance of mammals. This includes regulation of the estrous cycle, pregnancy, parturition and milk production.

Any disturbance of such processes of the corpus luteum will lead to reproductive disturbances in the farm animals. 
Early observations demonstrated the capacity of hypophyseal extracts to prolong the normal estrous cycle in rats and mice (Teel 1926), prolactin in particular ( $\mathrm{Lahr}$ and Riddle 1936) possessing such luteotropic activity.

Newly Takayoma and Greenwald (1973) proved that prolactin acts as the principal luteotropic hormone in the rat. The latter results would be comparable with a study involving pregnant rats (Greenwald and Johnson 1968).

It was found that prolactin is not the principal luteotropic factor as in the rat (Mayer, 1951). Kilpatrick et al. (1964) and Rennie et al. (1964) reported that prolactin is neither luteotropic when administered alone to hypophysectomized pseudopregnant rabbits nor luteolytic in intact rabbits.

The aim of this work is to study the hormonal changes which occur during formation, maintenance and involution of the corpora lutea of rabbits.

\section{Materials and Methods}

The levels of thyrotrophic hormone (TSH), follicle stimulating hormone (FSH), luteinizing hormone (LH) and prolactin (LTH) in the pituitaries as well as the sera of rabbits during the growth and involution of the corpus luteum were assayed.

Some trials were done to induce ovulation in rabbits. For this purpose 40 Boscat immature female rabbits were employed using various types of commercial gonadotrophic hormones. The best results were obtained by injecting the animals with PMS (Prolan A, Bayer) followed by a single injection of HCG (Roussel) after 2 days (Labib 1974).

In the main experiment 30 Boscat female rabbits were used. The animals were 3 months old and of an average body weight of $800-900 \mathrm{~g}$.

The animals were divided into 3 groups of 10 animals each. They were slaughtered after 3 , 7 and 15 days, respectively, after HCG injection. Individual samples of blood were collected from the animals. Each blood sample first allowed to clot, was centrifuged at 3000 r. p. m. for 15 minutes. Equal volumes of the sera of animals of each group were pooled and kept deep frozen until processing. The serum proteins together with pituitary hormones were separated and precipitated according to Szege and Roberts (1947).

The pituitary glands of the rabbits were weighed with a torsion balance, then dried with acetone. The pituitaries of each group were ground in a mortar, then dissolved in saline so that $1 \mathrm{mg}$. fresh weight was contained in $0.4 \mathrm{ml}$. saline.

Thyrotrophic hormone (TSH) was assessed in the test material by using the one-day-old chick thyroid weight response as a criterion (Bergman and Turner 1939). Histological sections were made from the thyroid glands of the three groups of rabbits and stained with hematoxylin and eosin. The vesicle diameter and epithelial cell heights were measured by using a calibrated micrometer ocular, to reflect indirectly the amount of TSH circulating in the blood.

The assay of FSH was done by the method adopted by Brown (1955) which depends upon the augmentation effect of HCG on FSH.

The level of luteinizing hormone in the pituitary and serum extracts of rabbits was determined by using the method adopted by Soliman (1960).

For determination of prolactin (LTH) in the pituitary and serum extracts the pigeon crop sac method after Grosvenor and Turner (1958) was used.

Standard log-dose response curves for TSH, FSH, LH and LTH were constructed under the same conditions by injecting standard hormones in graded doses in control groups.

The formula used for calculation of the slope of regression $b$ of the specific responses as influenced by the dose of the standard hormone administered was:

$$
b=\frac{\sum x y-\frac{\left(\sum x\right) \cdot(\Sigma y)}{n}}{\sum x^{2}-\frac{\left(\sum x\right)^{2}}{n}}
$$

According to Dixon and Massay (1956) this value was used for the determination of the I. U. corresponding to the thyroid weights in case of $\mathrm{TSH}$, the corpora haemorrhagica in case of $\mathrm{LH}$, ovary weights in case of FSH and the surface area of proliferation in the crop sac in case of prolactin by using the following formula:

$\bar{y} x=\bar{y}+b(x-\bar{x})$ where,

$\bar{y} x=$ the average response value of test material,

$\bar{y}=$ total average of response values of standard hormone, 
$x=$ unknown log-dose,

$\bar{x}=$ the average logs of doses of standard hormone.

Analysis of variance and $t$ test were performed to evaluate the differences between groups.

\section{Results}

The data presented in Tables 1 to 5 represent the changes in the concentration of TSH, FSH, LH and LTH in the pituitaries and sera of rabbits at the intervals of 3,7 and 15 days after ovulation.

Changes in thyroid histology

The histological picture of the thyroid gland of the rabbits corresponding to the stage of development and involution of the corpus luteum revealed the following:

When the age of the corpus luteum was 3 days the thyroids were considered euthyroid being characterized by vesicles of moderately variable sizes with an average diameter of $59.59 \pm 0.66 \mu$. The epithelial cells had a cuboidal form with an average height of $6.10 \pm 0.22 \mu$ (Table 2). The thyroid glands of rabbits possessing corpora lutea of an age of 7 days were relatively hypothyroid when compared with the 3 days old corpus luteum group.

Fig. 1.

Hormonal changes in the sera of rabbits during the stages of growth and involution of corpora lutea.

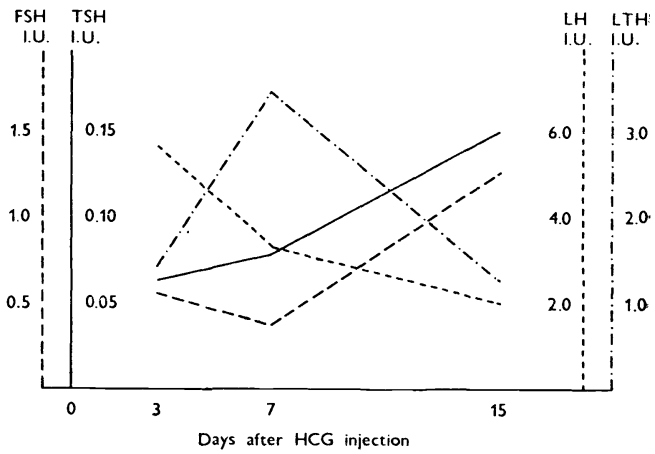

Table 1

Changes in the thyrotrophic hormone contents of the pituitaries and sera of rabbits during the stages of growth and involution of corpora lutea

\begin{tabular}{|c|c|c|c|c|}
\hline \multirow{2}{*}{$\begin{array}{c}\text { Time after } \\
\text { injection of } \\
\text { (HCG) (days) }\end{array}$} & $\begin{array}{c}\text { Pverage chick thyroid weights } \\
\mathrm{mg} / 100 \mathrm{~g} \text { body weight }\end{array}$ & $\begin{array}{c}\text { I. U./mg } \\
\text { fresh weight }\end{array}$ & $\begin{array}{c}\text { Average chick thyroid weights } \\
\text { mg/100 } \mathrm{g} \text { body weight }\end{array}$ & I. U./ml \\
\cline { 2 - 5 } 3 & $\mathrm{a}_{12.63 \pm 1.32}$ & 0.050 & $13.52 \pm 1.10$ & 0.062 \\
7 & $\mathrm{a}, \mathrm{b} 8.53 \pm 1.04$ & 0.014 & $14.24 \pm 0.33$ & 0.083 \\
15 & $\mathrm{~b}_{13.30 \pm 0.41}$ & 0.060 & $* 16.09 \pm 0.36$ & 0.148 \\
\hline
\end{tabular}

a Significantly different from each other at $P<0.05$

b Significantly different from each other at $P<0.01$

* Significantiy different from other groups at $P<0.01$

\pm Standard error 
Table 2

Epithelial cell height and vesicular diameter in micron of the thyroid gland during growth and involution of the corpus luteum

\begin{tabular}{|c|c|c|}
\hline Days after HCG injection & Epith. cell height $(\mu)$ & Vesicle diameter $(\mu)$ \\
\hline 3 & $\mathrm{a}_{6.10 \pm 0.22}$ & $\mathrm{a}_{59.59 \pm 0.66}$ \\
7 & $\mathrm{a}_{4.60 \pm 0.20}$ & $* 77.38 \pm 3.84$ \\
15 & $* 8.38 \pm 0.27$ & $\mathrm{a}_{54.72 \pm 0.21}$ \\
\hline
\end{tabular}

a Significantly different from each other at $P<0.01$

* Significantly different from other groups at $P<0.01$

\pm Standard error

Table 3

Changes in the follicle stimulating hormone contents of the pituitaries and sera of rabbits during the stages of growth and involution of the corpora lutea

\begin{tabular}{|c|c|c|c|c|}
\hline $\begin{array}{c}\text { Time after } \\
\text { injection of } \\
\text { HCG (days) }\end{array}$ & \multicolumn{2}{|c|}{ Pituitaries } & \multicolumn{2}{c|}{ Sera } \\
\cline { 2 - 6 } & $\begin{array}{c}\text { Average mice ovary weight } \\
\mathrm{mg} / 100 \mathrm{~g} \text { body weight }\end{array}$ & $\begin{array}{c}\text { I. U./mg fresh } \\
\text { weight }\end{array}$ & $\begin{array}{c}\text { Average mice ovary weight } \\
\text { mg/100 g body weight }\end{array}$ & I. U./ml \\
\hline 3 & $* 42.78 \pm 2.72$ & 1.402 & $32.60 \pm 2.71$ & 0.562 \\
7 & $34.38 \pm 1.55$ & 0.660 & $28.00 \pm 1.06$ & 0.372 \\
15 & $31.12 \pm 2.40$ & 0.491 & $* 41.27 \pm 1.60$ & 1.225 \\
\hline
\end{tabular}

* Significantly different from other groups at $P<0.01$

\pm Standard error

The thyroids of the rabbits having corpora lutea 15 days old showed a relatively hyperthyroid state (within physiological limits) as compared to the previous groups. The vesicle diameter was the lowest and the epithelial lining of the vesicles was the highest of the three groups studied. Such differences were statistically significant and evidently coincided with parallel changes in the levels of TSH in the pituitaries and sera of these rabbits.

\section{Discussion}

In this investigation the variation in the hormonal activities in both pituitaries and serum were studied during the growth and involution of the corpus luteum in rabbits. Most of the research workers have studied the hormonal control of corpus luteum maintenance by injections of various hormones either in intact or hypophysectomized animals. These methods did not represent the normal picture. But in this study the hormonal changes were studied without injecting any hormone or substance which may interfere with other hormones during the process of growth and involution. Under such physiological conditions, the real changes can be studied which are the base for further investigations.

Although recently attention has been given to radioimmunological and immunological methods for the assay of hormones, the biological methods, which were used in this study, have been reported to be more reliable (Immura et al. 1965; Sato et al. 1968). 
As shown form the results, it is clear that at the 3rd day after ovulation (beginning of growth of corpus luteum), there was an increase in the release of $\mathrm{LH}$ from the pituitary and its level was maximum in the serum. Since the biological halflife of LH does not exceed 30 minutes (Parlow 1968; Dekrester et al. 1973; Scanes and Follett 1973), and since the first blood sample obtained from HCG-treated rabbits was after 3 days, they would have been HCG-free.

This excess in LH on the 3rd day is of endogenous origin and is necessary to stimulate luteinization of the follicular granulosa cells.

Hilliard et al. (1968) stated that LH in addition to inducing ovulation is the initial activator of the growth of corpus luteum in rabbits, though not the major activator yet essentially involved in the transformation of granulosa cells to luteal ones.

The gradual decrease in $\mathrm{LH}$ level in the serum and the decreased release of this hormone from the pituitary after day 3 through day 15 may be attributed to a negative feed-back between LH and progesterone (luteal hormone). Again it is difficult to say, whether progesterone is secreted in high enough amounts on the 3rd day, which in turn can influence the LH secretion. But Canning (1966) has reported that when granulosa cells, harvested from follicles of the mare, are cultured, they have undergone morphological changes of luteinization in addi-

Table 4

Changes in the luteinizing hormone contents of the pituitaries and sera of rabbits during the stages of growth and involution of the corpora lutea

\begin{tabular}{|c|c|c|c|c|}
\hline $\begin{array}{c}\text { Time after } \\
\text { injection of } \\
\text { HCG (days) }\end{array}$ & $\begin{array}{c}\text { Po. of corpora } \\
\text { haemorrhagica/mouse }\end{array}$ & $\begin{array}{c}\text { I. U./mg fresh } \\
\text { weight }\end{array}$ & $\begin{array}{c}\text { Sera } \\
\text { haemorrhagica/mouse }\end{array}$ & I. U./ml \\
\hline 3 & $0.67 \pm 0.33$ & 2.424 & $\mathrm{a}, \mathrm{b}_{2.60} \pm 0.45$ & 5.610 \\
7 & $1.20 \pm 0.41$ & 3.034 & $\mathrm{a}_{1.22} \pm 0.20$ & 3.062 \\
15 & $0.80 \pm 0.24$ & 2.548 & $\mathrm{~b}_{0.25} \pm 0.05$ & 2.000 \\
\hline
\end{tabular}

a Significantly different from each other at $P<0.05$

b Significantly different from each other at $P<0.01$

\pm Standard error

Table 5

Changes in the prolactin contents of the pituitaries and sera of rabbits during the stages of growth and involution of the corpora lutea

\begin{tabular}{|c|c|c|c|c|}
\hline $\begin{array}{c}\text { Time after } \\
\text { injection of } \\
\text { HCG (days) }\end{array}$ & $\begin{array}{c}|c| \\
\text { Prea of proliferation of } \\
\text { crop sac of pigeons (CM) }\end{array}$ & $\begin{array}{c}\text { I. U./mg fresh } \\
\text { weight }\end{array}$ & $\begin{array}{c}\text { Sera } \\
\text { Area of proliferation of } \\
\text { crop of pigeons (CM) }\end{array}$ & I. U./ml \\
\cline { 2 - 6 } 3 & $3.40 \pm 0.41$ & 1.331 & $2.24 \pm 0.19$ & 1.358 \\
7 & $\mathrm{a}_{2.98} \pm 0.19$ & 1.199 & $* 3.53 \pm 0.38$ & 3.400 \\
15 & $\mathrm{a}_{4.53 \pm 0.17}$ & 1.513 & $2.14 \pm 0.43$ & 1.219 \\
\hline
\end{tabular}

a Significantly different from each other at $P<0.01$

* Significantly different from other groups at $P<0.05$

\pm Standard error 
tion to secreting steroids that are characteristic of luteal tissue. The cells in culture secrete primarily progesterone plus 20-dihydroprogesterone.

Spies et al. (1966) reported that injection of $\mathrm{LH}$ on the 4th day of the cycle causes luteolysis. This luteolytic effect could not be demonstrated when LH was injected on the $3 \mathrm{rd}$ day. The authors were unable to explain this phenomenon.

In this investigation the LH amount in the serum was high on the 3rd day, which denotes that high levels of LH are physiologically needed at this stage of development. After that time there is a sharp decrease in LH, during which the exogenous LH may interfere with synthesis or release of other hormones or substances necessary for development and maintenance of the corpus luteum and thence luteolysis occurred.

Hilliard et al. (1971) assumed that the luteolytic action of LH may be exerted in two ways, namely by luteinization of the follicles and thus reducing the source of estrogen, which has a luteotropic effect (Robson 1937; Hammond and Robson 1951), and by depleting the stores of sterol precursor. This assumption of Hilliard and co-workers can declare the sharp decrease in the LH level in the blood after the third day.

As the LH amount in the serum decreased, the prolactin (LTH) increased from the 3rd to the 7th day. This increase in LTH can be due to increase in progesterone levels in the blood, which stimulates the release of prolactin as Caligaris et al. (1974) found in the rat. The increase in the amount of LTH at this period could prove that corpora lutea in rabbits depend in addition to other physiological activities on prolactin. Hilliard et al. (1968) stated that LTH caused hypertrophy of the interstitial tissue of the ovary and promoted cholesterol mobilization and steroidogenesis. At the same period (3-7 days) there was a drop in the FSH and $\mathrm{LH}$ amounts in the serum and decreased release of these hormones from the pituitary. This reduction is necessary to get to the LTH to exert its effect, as it has been reported that FSH and $\mathrm{LH}$ may interfere with the luteotropic function of LTH (Rothchild 1960).

As the FSH increased in the serum due to increased release from the pituitary (from the 7th to 15th day) the LTH amount in the serum decreased gradually and the release from the pituitary was blocked.

The gradual increase of FSH from the 7th day on is mostly due to the hypothyroid state (Soliman and Reineke 1952) at this stage of corpus luteum development (Table 2). This increase in FSH would promote the growth of new follicles, which under the effect of the low levels of LH present in the blood at this time secrete estrogen, in order to help and maintain the functional capacity of the corpus luteum during this period of development.

Concerning the thyrotrophic hormone (TSH) there was a decreased synthesis of this hormone in the pituitary at the 7th day. This decrease may be due to the inhibiting effect of progesterone (which is mostly maximal at that time) on the production of this hormone (Badawi and Soliman 1957; Heshmet 1972). On the 15th day there was an increased synthesis and release of TSH which is due to drop in the amount of circulating progesterone as the lutein cells show degenerative changes at this time (Labib 1974). One can present the hypothesis that the increase of TSH amount at the 15th day play a role in regression of the corpora lutea. It has been reported that TSH level is increased in the serum during diestrus in cows (Soliman et al. 1963) and buffaloes (Abdo 1962).

It could thus be suggested that $\mathrm{LH}$ is required for differentiation of granulosa 
cells to luteal cells. LTH completes further development and steroidogenesis. TSH finally enhances luteolysis and transformation of the corpora lutea to the albicans type.

\section{Hormonální změny $v$ průběhu vzniku a involuce corpus luteum u ramlic}

Na 30 ramlicích plemene Boscat byly sledovány změny v obsahu TSH, FSH, LH a LTH v průběhu vzniku, trvání a involuce žlutého tělíska. Ovulace byla u samic indukována gonadotropními hormony (PMS a HCG). Po podání HCG byly ramlice rozděleny do 3 skupin po 10 jedincích. Zviřata byla po 3,7 a 15 dnech po injekci utrácena. Výsledky pokusu ukázaly následující:

Corpus luteum 3. den

Rychlost syntézy a sekrece TSH a štítná žláza byly ve stabilizovaném euthyroidním stavu. V hypofýze byla zvýšena koncentrace FSH s poměrně nízkou hladinou hormonu v krvi, což svědčí o inhibované sekreci FSH v uvedeném stadiu vývoje žlutého tělíska.

Obsah LTH v hypofýze byl středně vysoký a nízký v séru.

Corpus luteum 7. den

Byl nalezen nejnižší obsah TSH v hypofýze (snižená rychlost syntézy) s mírnou nevýznamnou změnou $\mathrm{v}$ krevní hladině hormonu.

Śtítná žláza pokusných zvířat byla méně aktivní ve srovnání $\mathrm{s}$ předchozí skupinou.

Obsah FSH v hypofýze a v krvi byl signifikantně snižený (snižena rychlost syntézy i sekrece FSH). Obsah LH v hypofýze byl zvýšen a jeho obsah v krvi naopak snížen (snížená sekrece LH).

Obsah LTH v hypofýze byl poměrně nízký, zatímco v krvi dosáhl maxima svědčícího o zvýšené sekreci LTH.

Corpus luteum 15. den

Obsah TSH v hypofýze a v krvi byl maximální; syntéza i sekrece hormonu byly tedy zvýšeny. Štítná žláza vykazovala rovněž maximální aktivitu ve srovnání $s$ předchozími skupinami.

Obsah FSH v hypofýze byl poměrně nízký, zatímco jeho koncentrace $\mathrm{v}$ séru byla nejvyšší (tj. maximální rychlost sekrece FSH). Obsah LH v hypofýze byl nízký a v krvi nejnižší. Obsah LTH v hypofýze byl maximální, ale nejnižší v krvi (zvýšená syntéza hormonu blokováním sekrece).

Výsledky pokusu jsou $\mathrm{v}$ textu diskutovány.

Гормональные изменения в процессе возникновения и инволюции желтого тела крольчихи

Над 30 крольчихами племени Боскат проводились наблюдения изменений содержания TSH, FSH, LH и LTH в процессе возникновения и инволюцин желтого тела. Индукция овуляции крольчих проводилась гонадотропными гормонами (PMS и HCG). После ввода HCG были крольчихи разделены на три группы по десять животных. На 3,7 и 15 день после укола были животные умерщвлены. Результаты опыта выявили следующее: 
Желтое тело на 3 день

Скорость синтеза и выделения TSH и щитовидная железа находились в стабилизованном евтироидном состоянии. В гипофизе была установлена повышенная концентрация FSH с довольно низким уровнем гормона в крови, что свидетельствует об ингибированном выделении FSH на упомянутой стадии развития желтого тела.

Содержание LTH в гипофизе находилось на среднем уровне и низким было в сыворотке.

Желтое тело на 7 день

Было установлено самсе низкое содержание TSH в гипофизе (пэниженная скорость синтеза) с незначительным изменением гормона в уровне крови.

Щитовидная железа подопытных животных отличалась по сравнению с предыдущей группой меньшей активностью.

Содержание FSH в гипофизе и крови было явно пониженным (понижение скорости синтеза и выделения FSH). Содержание LH в гипофизе было увеличено и содержание в крови, наоборот, понижено (пониженная секреция LH].

Содержание LTH в гипофизе было сравнительно низким, между тем как в крови достигало максимума, свидетельствующего о повышенной секреции LTH.

Желтое тело на 15 день

Содержание TSH в гипофизе и крови было максимальным, следовательно синтез и секреция гормона были повышенными. Щитовидная железа также отличалась максимальной активностью по сравнению с предыдущими группами.

Содержание FSH в гипофизе было сравнительно низким, между тем как его концентрация в сыворотке была самой высокой (т. е. максимальная скорость секреции FSH). Содержание LH в гипофизе было низким и в крови самым низким. Содержание LTH в гипофизе было максимальным, однако, самым низким в крови (повышенный синтез гормона блокировкой секреции).

\section{References}

ABDO, M. S.: Hormonal variations in the blood of buffaloes during pregnancy. M. D. Vet. Thesis, University of Cairo, 1962.

BADAWI, H. M. - SOLIMAN, F. A.: The influence of eostrogen and progesterone on pituitary function. Experimenta, 13, 1957: 412.

BERGMAN, A. J. - TURNER, C. W.: A comparison of the guinea pig and chick thyroid in the assay of thyrotrophic hormone. Endocrinology, 24, 1939: 656.

BROWN, P. S.: The assay of gonadotrophin from urine of nonpregnant human subjects. J. Endocrin., 13, 1955 : 59.

CALIGARIS, L. - ASTRADA, J. J. - TALEISNIK, S.: Oestrogen and progesterone influence on the release of prolactin in ovariectomized rats. J. Endocrin., 60, 1974: 205.

CHANNING, C. P.: Progesterone biosynthesis by equine granulosa cells growing in tissue culture. Nature, 210, 1966: 1266.

DEKRESTER, D. M. - ATKINS, R. C. - PANLEN, C. A.: Role of the kidney in the metabolism of luteinizing hormone. J. Endocrin., 58, 1973: 525.

DIXON, J. - MASSAY, F. J.: Introduction to statistical analysis, 2nd. Ed. McGrow-Hill Book Company, Inc. New York 1957.

GREENWOLD, G. S. - JOHNSON, D. C.: Gonadotrophic requirements for the maintenance of pregnancy in hypophysectomized rat. Endocrinology, 83, 1968: 1052. 
GROSVENOR, C. E. - TURNER, C. W.: Assay of lactogenic hormone. Endocrinology, 63, 1958: 530.

HAMMOND, J. Jr. - ROBSON, J. M.: Local maintenance of the rabbit corpus luteum with oestrogen. Endocrinology, 49, $1951: 384$.

HESHMET, H. A.: Influence of gonadotrophic hormones on thyroid function. Master Thesis, University of Cairo 1972.

HILLIARD, J. - SPIES, H. G. - LUCAS, L. - SAWYER, C. H.: Effect of prolactin on progestin release and cholesterol storage by rabbit ovarian interstitium. Endocrinology, 82, 1968: 122.

HILLIARD, J. - SOLDARINI, R. J. - SPIES, H. G. - SAWYER, C. H.: Luteotrophic and luteolytic actions of LH in hypophysectomized pseudopregnant rabbits. Endocrinology, 89, $1971: 513$.

IMURA, H. - SPARKES, L. L. - GRODSKY, G. H. - FORSHARM, P. H.: Immunologic studies of adrenocorticotrophic hormone (ACTH) dissociation of biological and immunologic activities. J. Clin. Endocrin., 25, 1965: 1361.

KILPATRICK, R. - ARMSTRONG, D. T. - GREEP, R. O.: Maintenance of corpus luteum by gonadotrophine in the hypophysectomized rabbits. Endocrinology, 74, 1964: 453.

LABIB, F.: Hormonal control of growth and involution of the corpus luteum of the rabbit. Master Thesis, University of Cairo 1974.

LAHR, E. L. - RIDDLE, O.: Temporary suppression of oestrus cycle in the rat by prolactin. Proc. Soc. Exp. Biol. N. Y., 34, 1936: 880.

PARLOW, A. E.: In gonadotrophins. pp. 59, 65, Ed. Rosenberg, E., Altos, California, Geron, X Inc., 1968.

RENNIE, P. - DAVIS, J. - FRIEDRICH, E.: Failure of ovine prolactin to show luteotrophic effects in the rabbit. Endocrinology, 75, 1964: 622 .

ROBSON, J. M.: Maintenance by oestrin of the luteal function in hypophysectomized rabbits. J. Physiol., 90, 1937: 435.

ROTHCHILD, I.: The corpus luteum-pituitary relationship. The lack of an inhibiting effect of progesterone on the secretion on the pituitary luteotropin. Endocrinology, 67, 1960: 54.

SATO, T. - KOIZURUI, K. - TUSUKNI, Y.: Further observation of the immunologic determination for human luteinizing hormone. Endocrin. Jap., 15, 1968: 299.

SCANNES, G. G. - FOLLETT, B. K.: The half life of luteinizing hormone in the circulation of domestic fowl and Japanese quail. J. Endocrin., 58, 1975: 125.

SOLIMAN, F. A.: Assaying luteinizing hormone. Nature, 194, 1960: 145.

SOLIMAN, F. A. - REINEKE, E. P.: Changes in uptake of radioactive iodine by the thyroid of rat during the oestrous cycle. Am. J. Physiol., 178, 1954: 89.

SOLIMAN, F. A. - NASR, H. - ZAKI, K.: Levels of thyroid and thyrotrophic hormones in the blood of Friesian cows at various reproductive stages. J. Reprod. Fertil., 6, 1963: 335.

SPIES, H. G. - COON, L. L. - GIER, H. T.: Luteolytic effect of LH and HCG on the corpora lutea of pseudopregnant rabbits. Endocrinology, 78, 1966: 67.

SZEGO, O. M. - ROBERTS, S.: The determination of protein-bound blood estrogen. Endocrinology, 41, 1947: 322 .

TAKAYAMA, S. - GREENWALD, G. S.: Hormonal requirements for the maintenance of luteal function in hypophysectomized, pseudopregnant rats. J. Endocrin., 56, 1975: 421.

TEEL, H. M.: The effects of injecting anterior hypophyseal fluid on the course of gestation in the rat. Am. J. Physiol., 79, 1926: 170. 